\title{
Sporcuların Zihinsel Antrenman Uygulamaları ve Özgüven Durumlarının İncelenmesi
}

\author{
Analysis of Athletes' Mental Training Practices and Self-Confidence Levels
}

\author{
Soner Çankaya* - Hacı Ali Çakıcı** - Ebru Yıldız ${ }^{* * *}-$ Yılmaz Aksoy ${ }^{* * * *}$
}

\begin{abstract}
The aim of the present study is to find out athletes' mental training practices and self-confidence levels according to some demographic information and to analyze the relationship between these. Descriptive relational survey model was used in the study. The population of the study consists of athletes studying at Samsun Ondokuz Mayıs University Yaşar Doğu Sport Sciences Faculty during the academic year 2019-2020. The sample of the study consists of 295 athletes who were studying at Samsun Ondokuz Mayis University Yaşar Doğu Sport Sciences Faculty and who were chosen with random sampling method. In the study, "The Sport Mental Training Questionnaire - SMTQ" which was developed by Behnke et al. (2017) and adapted by Yarayan and İlhan (2018), "Self-confidence Scale" developed by Akın (2007) and "Personal Information Form" developed by the researcher were used as data collection tool. For the assessment of the data obtained from the study, based on the normality assumption controls, Mann Whitney-U test or Student t-test were used for paired comparisons, while Kruskal Wallis H test or one-way ANOVA and Tukey multiple comparison test were used for the comparison of three or more groups. The relationship between the athletes' mental training practices and their self-confidence states was determined with Pearson Correlation coefficient. It was found that the students did not differ significantly in terms of the variables of gender, age, being a national team athlete and being a club's athlete in the SMTQ and Self-confidence Scale. In the SMTQ, there were significant differences in interpersonal skills and mental imagery sub-dimensions in terms of the variable of sport type; in interpersonal skills and total scale in terms of the variable of sport age; in mental performance skills in terms
\end{abstract}

\footnotetext{
* Prof. Dr., Ondokuz Mayıs Üniversitesi, Yaşar Doğu Spor Bilimleri Fakültesi, Spor Yöneticiliği Bölümü Prof. Dr., Ondokuz Mayıs University, Yaşar Doğu Faculty of Sport Sciences, Department of Sports Management ORCiD 0000-0001-8056-1892 scankaya@omu.edu.tr

**Arş. Gör., Ondokuz Mayıs Üniversitesi, Yaşar Doğu Spor Bilimleri Fakültesi, Spor Yöneticiliği Bölümü Res. Assist. Ondokuz Mayıs University, Yaşar Doğu Faculty of Sport Sciences, Department of Sports Management ORCID 0000-0001-9439-1118

haciali.cakici@omu.edu.tr

**** Yüksek Lisans Öğrencisi, Ondokuz Mayıs Üniversitesi, Yaşar Doğu Spor Bilimleri Fakültesi, Spor Yöneticiliği Bölümü MSc student, Ondokuz Mayıs University, Yaşar Doğu Faculty of Sport Sciences, Department of Sports Management ORCID 0000-0002-1363-0111 ebru.yildiz1695@gmail.com

***** Dr., Samsun Gençlik ve Spor İl Müdürlüğü

Dr., Samsun Provincial Directorate of Youth and Sports

ORCID 0000-0001-9036-1835

yilmazaksoy5552@gmail.com

Cite as/ Atıf: Çankaya, S., Çakıcı, H.A., Yıldız, E. \& Aksoy, Y. (2020). Sporcuların zihinsel antrenman uygulamaları

ve özgüven durumlarının incelenmesi.

https://dx.doi.org/10.29228/TurkishStudies.41690

Received/Geliş: 08 February/Şubat 2020

Accepted/Kabul: 20 June/Haziran 2020

Copyright $($ INTAC LTD, Turkey

Turkish Studies - Social, 15(4), 1805-1821.

Checked by plagiarism software

Published/Yayın: 25 June/Haziran 2020

CC BY-NC 4.0
} 
of the variable of department; in interpersonal skills, self-talk and mental imagery skills sub-dimensions and total score in terms of the variable of income level. In Self-confidence Scale, significant differences were found in all sub-dimensions and total score in terms of the variable of sport age; in internal self-confidence subdimension and total score in terms of the variable of income level. A significant positive association was found between athletes' mental training practices and self-confidence levels. Thus, it is expected that in case of including mental training practices for the sport field they are performing in, athletes can have increases in their self-confidence levels.

Structured Abstract: It is known that for athletes to be successful, they should be mentally ready for training or competitions besides being physically strong and ready. This topic, which covers sport psychology, has become more important recently. Mental training practices are now emphasized as much as physical training. Mental training practices contribute to the best display of movements during competition and training period by visualizing the movements in the mind and thinking that the movement is carried out in the best way. Another topic that is within the context of sport psychology is self-confidence. Self-confidence can be expressed as an emotion that affects each moment of individuals' lives. It is obvious that this situation creates a great effect on athletes as well. It can be said that athletes' mental training practices and high self-confidence feelings form a bond that connects each other in the success they gain. Thus, the aim of our study is to obtain the results of the relationship between athletes' mental training practices and their self-confidence states and to reveal the original value of the study.

The population of the study consists of athletes studying at Ondokuz Mayıs University Yaşar Doğu Faculty of Sport Sciences during the 2019-2020 Academic year. The sample of the study consists of 295 athletes who were chosen with random sampling method from the faculty. The data were collected with two scales and personal information form through questionnaire from. The Sport Mental Training QuestionnaireSMTQ, which was developed by Behnke et al. (2017) and adapted by Yarayan and İlhan (2018), consists of 20 items. There are five sub-dimensions as foundational skills, performance skills, interpersonal skills, selftalk and mental imagery. Self-confidence scale, which was developed by Akın (2007), consists of 33 items. It is a 5-Likert type scale and it consists of two sub-dimensions as internal and external self-confidence. High score taken from the scale shows high self-confidence level.

In the study, reliability coefficient was estimated to find out the internal consistency of the items. Reliability coefficients for the sub-dimensions of the SMTQ were found as 0.754 for foundational skills, 0.747 for performance skills, 0.832 for interpersonal skills, 0.778 for self-talk and 0.820 for mental imagery. Reliability coefficients for the sub-dimensions of Self-confidence scale were found as 0.871 for internal selfconfidence and as 0.861 for external self-confidence. Cronbach alpha coefficient of the Sport Mental Training Questionnaire was found as 0.925; while Cronbach Alpha coefficient of Self-confidence scale was found as 0.923 .

Mann Whitney U test for binary groups (gender, sport type, national and club athlete), and Kruskal Wallis $\mathrm{H}$ test for more than two groups (age, sports age, income status, division) were used in the evaluation of the data obtained from The SMTQ that do not show normal distribution. Student t-test for the binary groups, and One-way ANOVA with Tukey multiple comparison test for more than two groups were used in the evaluation of the data obtained from Self-confidence Scale that shows normal distribution. Pearson correlation coefficient was used to examine the level of relationship between athletes' mental training practices and their self-confidence states. The results were given as $\mathrm{n}(\%)$, mean, standard deviation, median and IQR values and the results were considered as significant at the level of $\mathrm{p}<0.05$.

In this study, it was determined that while no significant association was found in the study between mental training practices and self-confidence levels of athletes in terms of gender, age, being a national team athlete and being an athlete in a club; significant difference was found in some sub-dimensions in terms of the variables of sport type, sport age, department and level of income. Significant difference was found in interpersonal skills and mental imagery sub-skills of the mental training questionnaire in terms of the variable of sport type in the research group. In the analysis conducted, it was found that athletes who participated in team sports had higher interpersonal skills and mental imagery sub-skills average scores when compared with athletes who participated in individual sports. It can be thought that team athletes' acting together, interacting with each other and their need to communicate with each other all the time affect their interpersonal skill levels.

Turkish Studies - Social, 15(4) 
In addition, it can be said that team athletes' continuing their sport activities with different athletes and having a chance to observe different technical and tactical practices have a positive effect on their mental imagery practices. In the analysis of the relationship between athletes' mental training practices and their selfconfidence skills in terms of the variable of sport age, significant difference was found in the SMTQ total score and interpersonal skills sub-dimension. In the study, a significant difference was found in mental training questionnaire performance skills sub-dimension in terms of the variable of department. Also, significant difference was found in athletes' performance skills, self-talk, mental imagery sub-dimensions and sport mental training questionnaire total scores in terms of the variable of level of income. It was found that athletes' mental training practices and self-confidence levels increased as their level of income increased. It can be thought that financial concerns of athletes with low income have negative effects on their training processes and their selfconfidence. A positive association was found between athletes' mental training practices and their selfconfidence states. Thus, it can be said that the athletes include mental training practices in the sports they do and that this has an effect on their self-confidence. Athletes always see the pros and cons of their performance in training or competition. It can be said that mental training practices is a must to evaluate this situation positively. Thus, it can be said that they consider their mistakes and they realize that they must keep this in mind in order not to repeat them. It can be said that the fewer mistakes athletes make, the higher levels of success they have and their self-confidence reaches the highest level. As a conclusion, it can be said that regular and planned mental training practices will have positive effects on both their success and their self-confidence levels.

Keywords: Sports psychology, athlete, mental training, self-confidence, sport.

Öz: Bu araştırmanın amacı sporcuların bazı demografik bilgilerine göre zihinsel antrenman uygulamaları ile özgüven durum düzeylerini belirlemek ve bunlar arasındaki ilişkiyi incelemektir. Çalışmada betimsel nitelik taşıyan ilişkisel tarama modeli kullanılmıştır. Araştırmanın evrenini, 2019-2020 eğitim-öğretim döneminde, Samsun Ondokuz Mayıs Üniversitesi Yaşar Doğu Spor Bilimleri fakültesinde öğrenim gören sporcular oluşturmaktadır. Araştırmanın örneklemini ise, Ondokuz Mayıs Üniversitesi, Yaşar Doğu Spor Bilimleri Fakültesinde öğrenim gören tesadüfi örneklem yöntemi ile seçilen 295 sporcu oluşturmaktadır. Araştırmanın veri toplama araçları, Behnke ve arkadaşları (2017) tarafından geliştirilen, Yarayan ve İlhan (2018) tarafindan uyarlanan sporda zihinsel antrenman envanteri, Akın (2007) tarafından geliştirilen özgüven ölçeği ve araştırmacı tarafından geliştirilen "Kişisel Bilgi Formu" kullanılmıştır. Araştırmada elde edilen verilerin değerlendirilmesinde, normallik varsayım kontrollerine göre; ikili karşılaştırmalarda Mann Whitney-U testi veya Student t-testi, üç ve daha fazla grup kıyaslamalarında ise Kruskal Wallis H testi veya Tek Yönlü Varyans Analizi ve Tukey çoklu karşılaştırma testi uygulanmıştır. Sporcuların zihinsel antrenman uygulamaları ile özgüven durumları arasındaki ilişki Pearson korelasyon katsayısı ile belirlenmiştir. Sporcuların, sporda zihinsel antrenman envanteri ve özgüven ölçeğinde, cinsiyet, yaş, milli sporcu olma durumu ve kulüp sporcusu olma durumu değişkenlerine göre anlamlı düzeyde farklılaşmadığı saptanmıştır. Sporda zihinsel antrenman envanterinde, spor türü değişkenine göre, kişilerarası beceriler ve zihinsel canlandırma alt boyutlarında; spor yaşı değişkenine göre, kişilerarası beceriler alt boyutu ve toplam puanında; bölüm değişkenine göre, zihinsel performans becerileri alt boyutunda; gelir düzeyi değişkenine göre ise, zihinsel performans becerileri, kendinle konuşma ve zihinsel canlandırma alt boyutları ile toplam puanında anlamlı düzeyde farklılaştığı tespit edilmiştir. Özgüven ölçeğinde ise, spor yaşı değişkenine göre, tüm alt boyutlar ve toplam puanında; gelir düzeyi değişkenine göre ise, iç özgüven alt boyutunda ve toplam puanında anlamlı düzeyde farklılaştığı tespit edilmiştir. Sporcuların zihinsel antrenman uygulamaları ile özgüven düzeyleri arasında anlamlı düzeyde pozitif bir ilişki olduğu saptanmıştır. Dolayısıyla, sporcuların performans sergiledikleri spor alanı için zihinsel antrenman uygulamalarına yer vermeleri durumunda kendi özgüven düzeylerinde artış olabileceği beklenmektedir.

Anahtar Kelimeler: Spor psikolojisi, sporcu, zihinsel antrenman, özgüven, spor.

\section{Giriș}

Günümüz spor olgusunda, mağlubiyet ve galibiyet durumları arasındaki hassasiyet artmakta ve yükselen performans ve mücadele ruhu sporcuları fiziksel olduğu kadar psikolojik olarak da 
etkilemektedir (Yarayan ve İlhan, 2018). Bu bağlamda spor psikolojisi, giderek gelişen rekabet ortamı ile birlikte sadece fiziksel performansın yeterli olmayacağını anlayan sporcu ve antrenörler tarafından önemi kavranmaya başlanan bir bilim alanıdır (Karademir vd., 2018). Sporcuların aktif spor yaşantılarında karşılaşacakları olumlu veya olumsuz durumları ve o durumlar karşısında her zaman zihinsel olarak hazır olma hali zihinsel antrenman olarak tanımlanmaktadır (Koruç ve Bayar, 1990). Zihinsel antrenman uygulamaları, fiziksel yönden olmaksızın yapılacak hareketlerin sadece zihinde canlandırılması ve en iyi şekilde uygulandığını zihinde düşünülerek, müsabaka ve antrenman sürecinde en mükemmel şekilde sergilenmesinde katkı sağlamaktadır (Akandere vd., 2018). Spor psikolojisinde diğer bir faktör ise özgüven kavramıdır. Özgüven, bireylerin yaşantılarının her anını etkileyen bir duygu olarak ifade edilebilir. Bu durum sporcuların üzerinde de büyük bir etki sağladığı aşikardır. Belirli bir amaç yönünde ve başarı sağlama yolunda, spora katılım ve motivasyon yönünden özgüven duygusunun önemi çok büyüktür (Ekinci vd., 2014). Bunların yanında, araştırmanın gerekçesi olarak günümüzde sporcuların teknik-taktik ve fiziksel antrenman yönünden birçok donanıma ve bilgiye sahip olduğu bilinmektedir. Fakat zihinsel antrenman yönünden güçlü ve hazır olma kapasitelerinin ve özgüven durumlarının, fiziksel antrenman kadar önemli olduğu söylenebilir. Bu sebeple böyle bir araştırmanın yapılmasına ihtiyaç duyulmuştur. Spor psikolojisi üzerine yapılan araştırmalarda bunun önemini göstermektedir (Afacan 2019, Cebeci vd. 2019, Doğan 2019).

Alan yazın incelendiğinde yapılan çalışmalar, zihinsel antrenman ve özgüven olarak ayrı ayrı şekilde yapılmışır. Sporcuların, zihinsel antrenman uygulamaları ve özgüven duygularının yüksek olması, elde edecekleri başarıda birbirini bağlayan bir bağ oluşturduğu söylenebilir. Bu bilgiler ışı̆̆ında, bu çalışmanın amacı; sporcuların zihinsel antrenman uygulamaları ile özgüven durumları arasındaki ilişkinin incelenmesidir.

\section{Materyal ve Yöntem}

Araştırmada ölçeklerin uygulanabilmesi ve verilerin toplanabilmesi için Ondokuz Mayıs Üniversitesi, Sosyal ve Beşerî Bilimler Etik Kurulu'ndan 20/12/2019 tarih ve 2019/434 sayılı kararı ile onay alınmıştır.

Bu bölümde, araştırmada kullanılan model, araştırma grubu, veri toplama araçları ve araştırmada kullanılan istatiksel teknikler sırası ile açıklanmıştır.

\section{Evren ve Örneklem}

$\mathrm{Bu}$ araştırma, tarama modellerinden ilişkisel tarama modeli ile yapılmış betimsel bir çalışmadır. Tarama modelleri; geçmişte veya halen var olan bir durumu, var olduğu şekli ile betimlemeyi amaçlayan araştırma yaklaşımıdır (Karasar, 2000).

Araştırmanın evrenini, 2019-2020 Eğitim-Öğretim döneminde, Samsun Ondokuz Mayıs Üniversitesi Yaşar Doğu Spor Bilimleri fakültesinde öğrenim gören sporcular oluşturmaktadır. Araştırmanın örneklemini ise, Ondokuz Mayıs Üniversitesi, Yaşar Doğu Spor Bilimleri Fakültesinde öğrenim gören tesadüfi örneklem yöntemi ile seçilen 295 sporcu oluşturmaktadır.

\section{Veri Toplama Araçları}

Araştırmada veriler 2019-2020 Eğitim-Öğretim yılında Ondokuz Mayıs Üniversitesi, Yaşar Doğu Spor Bilimleri Fakültesinde eğitim gören üniversite öğrencilerinden anket yolu ile kullanılan ölçeklerden ve kişisel bilgi formundan toplanmıştır. Araştırmada araştırmacılar tarafından hazırlanan bir kişisel bilgi formu, geçerlik ve güvenirlik çalışmaları yapılmış 2 ölçek (Sporda Zihinsel Antrenman Envanteri ve Özgüven Ölçeği) kullanılmıştır. 
Kişisel bilgi formu, araştırmaya katılan sporcuların yaş, cinsiyet, spor türü, spor yaşı, okuduğu bölüm, gelir durumu, milli sporcu ve kulüp sporcusu olma durumunu içeren maddelerden oluşmaktadır.

Sporda Zihinsel Antrenman Envanteri: Behnke vd. (2017) tarafından geliştirilen, Yarayan ve İlhan (2018) tarafindan uyarlanan zihinsel antrenman envanteri 20 maddeden oluşmaktadır. Sporcuların zihinsel becerilerini ortaya çıkarmak için geliştirilen bu ölçekte, 5 alt boyut yer almaktadır. Bunlar; Zihinsel Temel Beceriler (3-7-10-14), Zihinsel Performans Becerileri (1-5-8-12-16-19), Kişilerarası Beceriler (4-11-15-18), Kendinle Konuşma (2-6-13) ve Zihinsel Canlandırma (9-17-20) şeklindedir. 5'li Likert tipi bir ölçme aracı olan zihinsel antrenman envanterinin en düşük puanı 20, en yüksek puanı ise 100'dür.

Özgüven Ölçeği: Akın (2007) tarafından geliştirilen özgüven ölçeği 33 maddeden oluşmaktadır. 5'li likert tipi bir ölçek olup, iç özgüven (1-3-4-5-7-9-10-12-15-17-19-21-23-25-2730-32) ve diş özgüven (2-6-8-11-13-14-16-18-20-22-24-26-28-29-31-33) olmak üzere 2 alt boyut içermektedir. Ölçek içerisinde alınan en yüksek puan, özgüven düzeyinin yüksek olduğunu göstermektedir. Ölçeğin en düşük puanı 33, en yüksek puanı ise 165'tir. Ölçekten alınan toplam puan ölçekte yer alan madde sayısına (33) bölünerek bireyin özgüven düzeyi hakkında bir sonuca varılabilir. Özgüven ölçeğinden elde edilen 2,5 puanın altı düşük, 2,5 ile 3,5 arası orta, 3,5 ve üzeri ise yüksek düzeyde özgüveni göstermektedir.

\section{İstatistiksel Analiz}

Envanterler sporculara dağıtılmadan önce araştırmanın amacı konusunda bilgi verilmiştir. $\mathrm{Bu}$ doğrultuda gerekli izinler alındıktan sonra uygulanmıştır. Verilerin toplanmasında herhangi bir süre kısıtlaması yapılmamıştır. Araştırmada, ölçek maddelerine verilen iç tutarlılığ kontrol etmek için güvenirlik katsayısı (cronbach alfa katsayısı) tahmin edilmiştir. Zihinsel antrenman envanteri alt boyutlarına ait güvenirlik katsayıları sırasıyla; zihinsel temel beceriler için 0,754, zihinsel performans becerileri için 0,747 , kişilerarası beceriler için 0,832 , kendinle konuşma için 0,778 ve zihinsel canlandırma için ise 0,820 olarak hesaplanmıştır. Özgüven ölçeği alt boyutlarına ait güvenirlik katsayıları sırasıyla, iç özgüven için 0,871 ve dış özgüven için 0,861 olarak hesaplanmıștır. Zihinsel antrenman envanteri cronbach alfa katsayısı, 0,925; özgüven ölçeği cronbach alfa katsayısı ise, 0,923 olarak saptanmışıtır. Verilerin istatistiksel değerlendirilmesinde öncelikli olarak normallik varsayımı Kolmogorov-Smirnov ve Shapiro-Wilk testi ile incelenmiştir. Normal dağılım göstermeyen Zihinsel antrenman uygulamaları ölçeğinden elde edilen verilerin değerlendirilmesinde ikili gruplar (cinsiyet, spor türü, milli ve kulüp sporcusu) için Mann Whitney U testi, ikiden fazla gruplar (yaş, spor yaşı, gelir durumu, bölüm) için ise Kruskal Wallis $\mathrm{H}$ testi uygulanmıştır. Normal dağılım gösteren özgüven ölçeğinden elde edilen verilerin değerlendirilmesinde ise ikili gruplar (cinsiyet, spor türü, milli ve kulüp sporcusu) için Student ttesti, ikiden fazla gruplar (yaş, spor yaşı, gelir durumu, bölüm) için Tek Yönlü Varyans Analizi ve Tukey çoklu karşılaştırma testi uygulanmıştır. Sporcuların zihinsel antrenman uygulamaları ile özgüven durumları arasındaki ilişki düzeyi ise Pearson korelasyon katsayısı ile incelenmiştir. Araştırmada elde edilen verilerin analizinde SPSS 21.0 V. İstatistik paket programı kullanılmıştır. Araştırma bulguları, n(\%), ortalama, standart sapma, ortanca değer ve IQR değerleri olarak verilmiş olup, bulgular $\mathrm{p}<0.05$ düzeyinde anlamlı kabul edilmiştir.

\section{Bulgular}

Araştırmaya gönüllü olarak katılan sporcuların (295 kişi) bazı demografik özelliklere göre dağılımı Tablo 1 'de verilmiştir. 
Tablo 1: Araştırmaya Katılan Sporcuların Demografik Özelliklerine Göre Dağılımı

\begin{tabular}{llrr}
\hline & & $\mathbf{n}$ & $\mathbf{\%}$ \\
\hline \multirow{2}{*}{ Cinsiyet } & Erkek & 236 & 80,0 \\
& Kadın & 59 & 20,0 \\
\hline \multirow{2}{*}{ Yaş } & $18-22$ & 209 & 70,8 \\
& $23-26$ & 74 & 25,1 \\
& 27 ve üzeri & 12 & 4,1 \\
\hline \multirow{2}{*}{ Spor Türü } & Takım Sporu & 161 & 54,6 \\
& Bireysel Spor & 134 & 45,4 \\
\hline \multirow{4}{*}{ Spor Yaşı } & $0-2$ & 13 & 4,4 \\
& $3-5$ & 65 & 22,0 \\
& 6-8 & 72 & 24,4 \\
\multirow{2}{*}{ Okuduğu Bölüm } & 9 ve üzeri & 145 & 49,2 \\
& Spor Yöneticiliği & 113 & 38,3 \\
& Antrenörlük & 102 & 34,6 \\
\multirow{2}{*}{ Milli Sporcu } & Beden Eğitimi Öğretmenliği & 80 & 27,1 \\
\hline \multirow{2}{*}{ Kulüp Sporcusu } & Evet & 41 & 13,9 \\
& Hayır & 254 & 86,1 \\
\hline \multirow{3}{*}{ Gelir Durumu } & Evet & 159 & 53,9 \\
& Hayır & 136 & 46,1 \\
\hline & Gelir $<$ Gider (Düşük) & 89 & 30,2 \\
& Gelir=Gider (Orta) & 174 & 59,0 \\
& Gelir>Gider (Yüksek) & 32 & 10,8 \\
\hline
\end{tabular}

Kadın ve erkek sporcuların zihinsel antrenman uygulamaları ve özgüven durumları Tablo 2 'de verilmiştir.

Tablo 2: Cinsiyete Göre Sporcuların Zihinsel Antrenman Uygulamaları ile Özgüven Durumları

\begin{tabular}{|c|c|c|c|c|c|c|c|}
\hline Alt Boyutlar & Cinsiyet & $\mathrm{n}$ & Ort. & Ss. & Ortanca & IQR & $\mathrm{P}$ \\
\hline \multirow{2}{*}{ Zihinsel Temel Beceriler* } & Erkek & 236 & 15,56 & 3,16 & 16,00 & 4,0 & \multirow{2}{*}{0,484} \\
\hline & Kadın & 59 & 15,49 & 2,76 & 16,00 & 2,0 & \\
\hline \multirow{2}{*}{$\begin{array}{l}\text { Zihinsel Performans } \\
\text { Becerileri* }\end{array}$} & Erkek & 236 & 21,90 & 4,15 & 22,00 & 5,0 & \multirow{2}{*}{0,302} \\
\hline & Kadın & 59 & 21,53 & 3,62 & 22,00 & 4,0 & \\
\hline \multirow{2}{*}{ Kişilerarası Beceriler* } & Erkek & 236 & 16,37 & 2,99 & 17,00 & 2,0 & \multirow{2}{*}{0,190} \\
\hline & Kadın & 59 & 16,83 & 2,86 & 17,00 & 3,0 & \\
\hline \multirow{2}{*}{$\begin{array}{l}\text { Kendinle Konuşma } \\
\text { Becerisi* }\end{array}$} & Erkek & 236 & 11,51 & 2,60 & 12,00 & 3,0 & \multirow{2}{*}{0,141} \\
\hline & Kadın & 59 & 11,97 & 2,64 & 12,00 & 3,0 & \\
\hline \multirow{2}{*}{ Zihinsel Canlandırma* } & Erkek & 236 & 11,74 & 2,64 & 12,00 & 3,0 & \multirow{2}{*}{0,925} \\
\hline & Kadın & 59 & 11,95 & 2,19 & 12,00 & 3,0 & \\
\hline \multirow{2}{*}{$\begin{array}{l}\text { Sporda Zihinsel Antrenman } \\
\text { Envanteri Toplam Puan* }\end{array}$} & Erkek & 236 & 77,08 & 13,04 & 79,00 & 12,75 & \multirow{2}{*}{0,806} \\
\hline & Kadın & 59 & 77,76 & 12,02 & 79,00 & 11,00 & \\
\hline \multirow{2}{*}{ İç Özg } & Erkek & 236 & 4,04 & 0,54 & & & \multirow{2}{*}{0,498} \\
\hline & Kadın & 59 & 3,99 & 0,58 & & & \\
\hline \multirow{2}{*}{ Dış Özgüven } & Erkek & 236 & 4,01 & 0,52 & & & \multirow[b]{2}{*}{0,4} \\
\hline & Kadın & 59 & 3,95 & 0,70 & & & \\
\hline \multirow{2}{*}{$\begin{array}{l}\text { Özgüven Ölçeği Toplam } \\
\text { Puan1 }\end{array}$} & Erkek & 236 & 4,03 & 0,50 & & & \multirow{2}{*}{0,463} \\
\hline & Kadın & 59 & 3,97 & 0,61 & & & \\
\hline
\end{tabular}

* ile gösterilenler parametrik olmayan teste (Mann Whitney U test) tabi tutulmuştur.

Araştırmada kadın ve erkek katılımcıların zihinsel antrenman uygulamaları ile özgüven düzeylerinde anlamlı bir farklılık tespit edilememiştir $(\mathrm{P}>0,05)$. (Tablo 2). 
Farklı yaş gruplarındaki sporcuların zihinsel antrenman uygulamaları ve özgüven durumları Tablo 3'de verilmiştir.

Tablo 3: Yaş Değişkenine Göre Sporcuların Zihinsel Antrenman Uygulamaları ile Özgüven Durumlarına İlişkin Analiz Sonuçları

\begin{tabular}{|c|c|c|c|c|c|c|c|}
\hline Alt Boyutlar & Yaş & $\mathrm{n}$ & Ort. & Ss. & Ortanca & IQR & $\mathrm{P}$ \\
\hline \multirow{3}{*}{ Zihinsel Temel Beceriler* } & $18-22$ & 209 & 15,48 & 3,14 & 16,00 & 4,0 & \multirow{3}{*}{0,647} \\
\hline & $23-26$ & 74 & 15,88 & 2,70 & 16,00 & 3,0 & \\
\hline & 27 ve üzeri & 12 & 14,67 & 4,05 & 15,50 & 6,0 & \\
\hline \multirow{3}{*}{$\begin{array}{l}\text { Zihinsel Performans } \\
\text { Becerileri* }\end{array}$} & $18-22$ & 209 & 21,76 & 4,14 & 22,00 & 6,0 & \multirow{3}{*}{0,874} \\
\hline & $23-26$ & 74 & 22,08 & 3,69 & 23,00 & 4,0 & \\
\hline & 27 ve üzeri & 12 & 21,50 & 4,76 & 23,00 & 7,0 & \\
\hline \multirow{3}{*}{ Kişilerarası Beceriler* } & $18-22$ & 209 & 16,49 & 3,05 & 17,00 & 3,0 & \multirow{3}{*}{0,801} \\
\hline & $23-26$ & 74 & 16,50 & 2,63 & 17,00 & 2,3 & \\
\hline & 27 ve üzeri & 12 & 15,75 & 3,62 & 16,50 & 1,8 & \\
\hline \multirow{3}{*}{ Kendinle Konuşma* } & $18-22$ & 209 & 11,56 & 2,61 & 12,00 & 3,0 & \multirow{3}{*}{0,488} \\
\hline & $23-26$ & 74 & 11,81 & 2,66 & 12,00 & 3,0 & \\
\hline & 27 ve üzeri & 12 & 11,17 & 2,17 & 11,50 & 3,5 & \\
\hline \multirow{3}{*}{ Zihinsel Canlandırma* } & $18-22$ & 209 & 11,85 & 2,57 & 12,00 & 3,0 & \multirow{3}{*}{0,292} \\
\hline & $23-26$ & 74 & 11,80 & 2,37 & 12,00 & 3,0 & \\
\hline & 27 ve üzeri & 12 & 10,50 & 3,32 & 11,50 & 3,8 & \\
\hline \multirow{3}{*}{$\begin{array}{l}\text { Sporda Zihinsel Antrenman } \\
\text { Envanteri Toplam Puan* }\end{array}$} & $18-22$ & 209 & 77,12 & 13,05 & 78,00 & 13,00 & \multirow{3}{*}{0,823} \\
\hline & $23-26$ & 74 & 78,07 & 11,48 & 79,00 & 10,25 & \\
\hline & 27 ve üzeri & 12 & 73,58 & 16,78 & 79,50 & 16,50 & \\
\hline \multirow{3}{*}{ İç Özgüven } & $18-22$ & 209 & 4,03 & 0,57 & & & \multirow{3}{*}{0,994} \\
\hline & $23-26$ & 74 & 4,03 & 0,49 & & & \\
\hline & 27 ve üzeri & 12 & 4,03 & 0,46 & & & \\
\hline \multirow{3}{*}{ D1ş Özgüven } & $18-22$ & 209 & 3,99 & 0,57 & & & \multirow{3}{*}{0,968} \\
\hline & $23-26$ & 74 & 4,01 & 0,55 & & & \\
\hline & 27 ve üzeri & 12 & 4,00 & 0,53 & & & \\
\hline \multirow{3}{*}{$\begin{array}{l}\text { Özgüven Ölçeği Toplam } \\
\text { Puanı }\end{array}$} & $18-22$ & 209 & 4,01 & 0,54 & & & \multirow{3}{*}{0,997} \\
\hline & $23-26$ & 74 & 4,02 & 0,49 & & & \\
\hline & 27 ve üzeri & 12 & 4,02 & 0,48 & & & \\
\hline
\end{tabular}

* ile gösterilenler parametrik olmayan teste (Kruskal Wallis H test) tabi tutulmuştur.

Yapılan araştırma sonucunda; araştırmaya katılanların yaş değişkenine göre zihinsel antrenman uygulamaları ile özgüven düzeyleri arasında anlamlı bir farklılık tespit edilememiştir (P>0,05). (Tablo 3).

Bireysel ve takım sporu ile ilgilenen sporcuların zihinsel antrenman uygulamaları ve özgüven durumları Tablo 4'de verilmiştir. 
Tablo 4: Spor Türü Değişkenine Göre Sporcuların Zihinsel Antrenman Uygulamaları ile Özgüven Durumlarına İlişkin Analiz Sonuçları

\begin{tabular}{|c|c|c|c|c|c|c|c|}
\hline Alt Boyutlar & Spor Türü & $\mathrm{n}$ & Ort. & Ss. & Ortanca & IQR & $\mathrm{P}$ \\
\hline \multirow{2}{*}{ Zihinsel Temel Beceriler* } & Takım & 161 & 15,50 & 2,71 & 16,00 & 3,0 & \multirow{2}{*}{0,122} \\
\hline & Bireysel & 134 & 15,60 & 3,48 & 16,00 & 4,0 & \\
\hline \multirow{2}{*}{$\begin{array}{l}\text { Zihinsel Performans } \\
\text { Becerileri* }\end{array}$} & Takım & 161 & 22,14 & 3,43 & 22,00 & 4,0 & \multirow{2}{*}{0,553} \\
\hline & Bireysel & 134 & 21,46 & 4,67 & 22,00 & 6,0 & \\
\hline \multirow{2}{*}{ Kişilerarası Beceriler* } & Takım & 161 & 16,93 & 2,56 & 17,00 & 3,0 & \multirow{2}{*}{0,011} \\
\hline & Bireysel & 134 & 15,90 & 3,32 & 17,00 & 3,0 & \\
\hline \multirow{2}{*}{$\begin{array}{l}\text { Kendinle Konuşma } \\
\text { Becerisi* }\end{array}$} & Takım & 161 & 11,71 & 2,38 & 12,00 & 2,0 & \multirow{2}{*}{0,763} \\
\hline & Bireysel & 134 & 11,47 & 2,85 & 12,00 & 4,0 & \\
\hline \multirow{2}{*}{ Zihinsel Canlandırma* } & Takım & 161 & 12,15 & 2,21 & 12,00 & 3,0 & \multirow{2}{*}{0,021} \\
\hline & Bireysel & 134 & 11,34 & 2,86 & 12,00 & 3,0 & \\
\hline \multirow{2}{*}{$\begin{array}{l}\text { Sporda Zihinsel Antrenman } \\
\text { Envanteri Toplam Puan* }\end{array}$} & Takım & 161 & 78,42 & 10,70 & 79,00 & 12,00 & \multirow{2}{*}{0,479} \\
\hline & Bireysel & 134 & 75,77 & 14,88 & 79,00 & 12,25 & \\
\hline \multirow{2}{*}{ İç Özgüven } & Takım & 161 & 3,99 & 0,54 & & & \multirow{2}{*}{0,161} \\
\hline & Bireysel & 134 & 4,08 & 0,55 & & & \\
\hline \multirow{2}{*}{ Dış Özgüven } & Takım & 161 & 4,00 & 0,52 & & & \multirow{2}{*}{0,954} \\
\hline & Bireysel & 134 & 4,00 & 0,60 & & & \\
\hline Özgüven Ölçeği Toplam & Takım & 161 & 3,99 & 0,50 & & & 0431 \\
\hline Puanı & Bireysel & 134 & 4,04 & 0,55 & & & \\
\hline
\end{tabular}

* ile gösterilenler parametrik olmayan teste (Mann Whitney U test) tabi tutulmuştur.

Araştırmada sporcuların spor türü değişkenine göre alt boyutlar açısından incelendiğinde, Kişilerarası Beceriler ve Zihinsel Canlandırma puanlarında anlamlı bir farklılık tespit edilirken $[(\mathrm{P}=0.003),(\mathrm{P}=0.006)]$, diğer alt boyutlar açısından anlamlı bir farklılık belirlenememiştir $(\mathrm{P}<0,05)$. (Tablo 4).

Farklı sporcu yaş gruplarındaki sporcuların zihinsel antrenman uygulamaları ve özgüven durumları Tablo 5'de verilmiştir.

Araştırmada katılımcıların spor yaşı durumuna göre Özgüven Ölçeği Toplam Puanında $(\mathrm{P}=0,006)$, İç Özgüven $(\mathrm{P}=0,041)$ ve Diş Özgüven $(\mathrm{P}=0,002)$ alt boyutlarında; Sporda Zihinsel Antrenman Envanteri Toplam Puanında $(\mathrm{P}=0,023)$ ve Kişilerarası Beceriler $(\mathrm{P}=0,015)$ alt boyutunda anlamlı bir farklılık tespit edilirken, diğer alt boyutlar açısından anlamlı bir farklılık belirlenememiştir $(\mathrm{P}<0,05)$. (Tablo 5). 
Tablo 5: Spor Yaşı Değişkenine Göre Sporcuların Zihinsel Antrenman Uygulamaları ile Özgüven Durumlarına İlişkin Analiz Sonuçları

\begin{tabular}{|c|c|c|c|c|c|c|c|}
\hline Alt Boyutlar & Spor Yaşı & $\mathrm{n}$ & Ort. & Ss. & Ortanca & IQR & $\mathrm{P}$ \\
\hline \multirow{4}{*}{ Zihinsel Temel Beceriler* } & $0-2$ & 13 & 15,54 & 2,54 & 16,00 & 3,0 & \multirow{4}{*}{0,225} \\
\hline & $3-5$ & 65 & 15,35 & 2,71 & 16,00 & 3,0 & \\
\hline & $6-8$ & 72 & 15,14 & 3,17 & 16,00 & 4,0 & \\
\hline & 9 ve üzeri & 145 & 15,83 & 3,23 & 16,00 & 3,0 & \\
\hline \multirow{4}{*}{$\begin{array}{l}\text { Zihinsel Performans } \\
\text { Becerileri* }\end{array}$} & $0-2$ & 13 & 20,69 & 3,40 & 21,00 & 4,0 & \multirow{4}{*}{0,143} \\
\hline & $3-5$ & 65 & 21,15 & 3,57 & 22,00 & 4,0 & \\
\hline & $6-8$ & 72 & 21,71 & 4,41 & 22,00 & 4,8 & \\
\hline & 9 ve üzeri & 145 & 22,29 & 4,09 & 23,00 & 5,0 & \\
\hline \multirow{4}{*}{ Kişilerarası Beceriler* } & $0-2$ & 13 & $15,62 \mathrm{~b}$ & 1,33 & 16,00 & 1,5 & \multirow{4}{*}{0,015} \\
\hline & $3-5$ & 65 & $16,15 \mathrm{a}$ & 2,37 & 17,00 & 2,5 & \\
\hline & $6-8$ & 72 & $16,61 \mathrm{a}$ & 3,53 & 17,50 & 3,0 & \\
\hline & 9 ve üzeri & 145 & $16,60 \mathrm{a}$ & 3,01 & 17,00 & 3,0 & \\
\hline \multirow{4}{*}{ Kendinle Konuşma* } & $0-2$ & 13 & 11,85 & 2,79 & 12,00 & 4,0 & \multirow{4}{*}{0,143} \\
\hline & $3-5$ & 65 & 11,08 & 2,31 & 12,00 & 3,5 & \\
\hline & $6-8$ & 72 & 11,54 & 2,97 & 12,00 & 4,0 & \\
\hline & 9 ve üzeri & 145 & 11,85 & 2,51 & 12,00 & 3,0 & \\
\hline \multirow{4}{*}{ Zihinsel Canlandırma* } & $0-2$ & 13 & 11,00 & 2,61 & 12,00 & 2,0 & \multirow{4}{*}{0,123} \\
\hline & $3-5$ & 65 & 11,55 & 2,18 & 12,00 & 2,0 & \\
\hline & $6-8$ & 72 & 11,54 & 3,08 & 12,00 & 4,0 & \\
\hline & 9 ve üzeri & 145 & 12,07 & 2,41 & 12,00 & 3,0 & \\
\hline \multirow{4}{*}{$\begin{array}{l}\text { Sporda Zihinsel Antrenman } \\
\text { Envanteri Toplam Puan* }\end{array}$} & $0-2$ & 13 & $74,69 \mathrm{~b}$ & 9,73 & 76,00 & 7,00 & \multirow{4}{*}{0,023} \\
\hline & $3-5$ & 65 & $75,29 \mathrm{~b}$ & 10,13 & 76,00 & 10,00 & \\
\hline & $6-8$ & 72 & $76,54 \mathrm{ab}$ & 14,34 & 79,00 & 12,75 & \\
\hline & 9 ve üzeri & 145 & $78,64 \mathrm{a}$ & 13,27 & 80,00 & 13,00 & \\
\hline \multirow{4}{*}{ İç Özgüven } & $0-2$ & 13 & $3,72 \mathrm{~b}$ & 0,55 & & & \multirow{4}{*}{0,041} \\
\hline & $3-5$ & 65 & $3,94 \mathrm{ab}$ & 0,54 & & & \\
\hline & $6-8$ & 72 & 4,03 a & 0,59 & & & \\
\hline & 9 ve üzeri & 145 & $4,10 \mathrm{a}$ & 0,51 & & & \\
\hline \multirow{4}{*}{ Dış Özgüven } & $0-2$ & 13 & $3,50 \mathrm{~b}$ & 0,47 & & & \multirow{4}{*}{0,002} \\
\hline & $3-5$ & 65 & $3,90 \mathrm{a}$ & 0,59 & & & \\
\hline & $6-8$ & 72 & $4,06 \mathrm{a}$ & 0,58 & & & \\
\hline & 9 ve üzeri & 145 & $4,06 \mathrm{a}$ & 0,51 & & & \\
\hline \multirow{4}{*}{$\begin{array}{l}\text { Özgüven Ölçeği Toplam } \\
\text { Puanı }\end{array}$} & $0-2$ & 13 & $3,62 \mathrm{~b}$ & 0,47 & & & \multirow{4}{*}{0,006} \\
\hline & $3-5$ & 65 & $3,92 \mathrm{a}$ & 0,54 & & & \\
\hline & $6-8$ & 72 & $4,04 \mathrm{a}$ & 0,55 & & & \\
\hline & 9 ve üzeri & 145 & $4,08 \mathrm{a}$ & 0,48 & & & \\
\hline
\end{tabular}

* ile gösterilenler parametrik olmayan teste (Kruskal Wallis $\mathrm{H}$ test) tabi tutulmuştur.

Farklı bölümlerde okuyan sporcuların zihinsel antrenman uygulamaları ve özgüven durumları Tablo 6'de verilmiştir. 
Tablo 6: Okuduğu Bölüm Değişkenine Göre Sporcuların Zihinsel Antrenman Uygulamaları ile Özgüven Durumlarına İlişkin Analiz Sonuçları

\begin{tabular}{|c|c|c|c|c|c|c|c|}
\hline Alt Boyutlar & $\begin{array}{l}\text { Okuduğu } \\
\text { Bölüm }\end{array}$ & $\mathrm{n}$ & Ort. & Ss. & Ortanca & IQR & $\mathrm{P}$ \\
\hline \multirow{3}{*}{ Zihinsel Temel Beceriler* } & SYB & 113 & 15,51 & 3,04 & 16,00 & 3,0 & \multirow{3}{*}{0,341} \\
\hline & ANT & 102 & 15,31 & 3,16 & 16,00 & 4,0 & \\
\hline & BSÖ & 80 & 15,89 & 3,03 & 16,00 & 3,0 & \\
\hline \multirow{3}{*}{$\begin{array}{l}\text { Zihinsel Performans } \\
\text { Becerileri* }\end{array}$} & SYB & 113 & $21,27 b$ & 3,74 & 21,00 & 4,5 & \multirow{3}{*}{0,037} \\
\hline & ANT & 102 & $22,24 \mathrm{a}$ & 4,15 & 23,00 & 5,0 & \\
\hline & BSÖ & 80 & $22,10 \mathrm{a}$ & 4,29 & 23,00 & 5,0 & \\
\hline \multirow{3}{*}{ Kişilerarası Beceriler* } & SYB & 113 & 16,23 & 2,97 & 16,00 & 3,0 & \multirow{3}{*}{0,254} \\
\hline & ANT & 102 & 16,55 & 2,91 & 17,00 & 3,0 & \\
\hline & BSÖ & 80 & 16,68 & 3,06 & 17,00 & 3,0 & \\
\hline \multirow{3}{*}{ Kendinle Konuşma* } & SYB & 113 & 11,19 & 2,55 & 12,00 & 3,0 & \multirow{3}{*}{0,057} \\
\hline & ANT & 102 & 11,92 & 2,67 & 12,00 & 5,0 & \\
\hline & BSÖ & 80 & 11,78 & 2,56 & 12,00 & 3,0 & \\
\hline \multirow{3}{*}{ Zihinsel Canlandırma* } & SYB & 113 & 11,62 & 2,27 & 12,00 & 2,0 & \multirow{3}{*}{0,230} \\
\hline & ANT & 102 & 11,89 & 2,82 & 12,00 & 3,3 & \\
\hline & BSÖ & 80 & 11,86 & 2,60 & 12,00 & 3,0 & \\
\hline \multirow{3}{*}{$\begin{array}{l}\text { Sporda Zihinsel Antrenman } \\
\text { Envanteri Toplam Puan* }\end{array}$} & SYB & 113 & 75,82 & 12,06 & 77,00 & 10,50 & \multirow{3}{*}{0,138} \\
\hline & ANT & 102 & 77,91 & 13,64 & 79,50 & 17,00 & \\
\hline & BSÖ & 80 & 78,30 & 12,77 & 79,50 & 11,00 & \\
\hline \multirow{3}{*}{ İç Özgüven } & SYB & 113 & 4,00 & 0,52 & & & \multirow{3}{*}{0,688} \\
\hline & ANT & 102 & 4,07 & 0,56 & & & \\
\hline & BSÖ & 80 & 4,03 & 0,57 & & & \\
\hline \multirow{3}{*}{ Dış Özgüven } & SYB & 113 & 3,94 & 0,56 & & & \multirow{3}{*}{0,347} \\
\hline & ANT & 102 & 4,02 & 0,57 & & & \\
\hline & BSÖ & 80 & 4,05 & 0,54 & & & \\
\hline \multirow{3}{*}{$\begin{array}{l}\text { Özgüven Ölçeği Toplam } \\
\text { Puanı }\end{array}$} & SYB & 113 & 3,97 & 0,50 & & & \multirow{3}{*}{0,526} \\
\hline & ANT & 102 & 4,04 & 0,53 & & & \\
\hline & BSÖ & 80 & 4,04 & 0,53 & & & \\
\hline
\end{tabular}

* ile gösterilenler parametrik olmayan teste (Kruskal Wallis $\mathrm{H}$ test) tabi tutulmuş̧ur.

Çalışmada, sporcuların okuduğu bölüm değişkeni bakımından zihinsel performans becerileri alt boyutunda anlamlı bir farklılık tespit edilirken, diğer alt boyutlar ve Özgüven düzeylerinde anlamlı bir farklılık olmadığı tespit edilmişstir $(\mathrm{P}<0,05)$. (Tablo 6).

Sporcuların millilik durumlarına göre zihinsel antrenman uygulamaları ve özgüven durumları Tablo 7'de verilmiştir. 
Tablo 7: Milli Sporcu Olma Durumuna Göre Sporcuların Zihinsel Antrenman Uygulamaları ile Özgüven Durumlarına İlişkin Analiz Sonuçları

\begin{tabular}{|c|c|c|c|c|c|c|c|}
\hline Alt Boyutlar & Milli Sporcu & $\mathrm{n}$ & Ort. & Ss. & Ortanca & IQR & $\mathrm{P}$ \\
\hline \multirow{2}{*}{ Zihinsel Temel Beceriler* } & Evet & 41 & 15,95 & 3,56 & 17,00 & 3,0 & \multirow{2}{*}{0,365} \\
\hline & Hayır & 254 & 15,48 & 3,00 & 16,00 & 3,0 & \\
\hline \multirow{2}{*}{$\begin{array}{l}\text { Zihinsel Performans } \\
\text { Becerileri* }\end{array}$} & Evet & 41 & 22,44 & 4,79 & 24,00 & 6,0 & \multirow{2}{*}{0,298} \\
\hline & Hayır & 254 & 21,72 & 3,92 & 22,00 & 4,3 & \\
\hline \multirow{2}{*}{ Kişiler Arası Beceriler* } & Evet & 41 & 16,32 & 3,53 & 17,00 & 3,5 & \multirow{2}{*}{0,739} \\
\hline & Hayır & 254 & 16,48 & 2,88 & 17,00 & 2,0 & \\
\hline \multirow{2}{*}{ Kendinle Konuşma Becerisi* } & Evet & 41 & 11,76 & 2,76 & 12,00 & 3,0 & \multirow{2}{*}{0,687} \\
\hline & Hayır & 254 & 11,57 & 2,59 & 12,00 & 3,0 & \\
\hline \multirow{2}{*}{ Zihinsel Canlandırma* } & Evet & 41 & 11,76 & 3,10 & 13,00 & 3,0 & \multirow{2}{*}{0,949} \\
\hline & Hayır & 254 & 11,78 & 2,47 & 12,00 & 3,0 & \\
\hline \multirow{2}{*}{$\begin{array}{l}\text { Sporda Zihinsel Antrenman } \\
\text { Envanteri Toplam Puan* }\end{array}$} & Evet & 41 & 78,22 & 16,17 & 81,00 & 13,50 & \multirow{2}{*}{0,590} \\
\hline & Hayır & 254 & 77,05 & 12,22 & 78,50 & 12,00 & \\
\hline \multirow{2}{*}{ İç Özgüven } & Evet & 41 & 4,13 & 0,52 & & & \multirow{2}{*}{0,236} \\
\hline & Hayır & 254 & 4,02 & 0,55 & & & \\
\hline \multirow{2}{*}{ Dış Özgüven } & Evet & 41 & 4,12 & 0,55 & & & \multirow{2}{*}{0,134} \\
\hline & Hayır & 254 & 3,98 & 0,56 & & & \\
\hline \multirow{2}{*}{ Özgüven Toplam Puanı } & Evet & 41 & 4,12 & 0,52 & & & \multirow{2}{*}{0,156} \\
\hline & Hayır & 254 & 4,00 & 0,52 & & & \\
\hline
\end{tabular}

* ile gösterilenler parametrik olmayan testlere (Mann Whitney U test ve Kruskal Wallis H test) tabi tutulmuştur.

Araştırma sonucunda; katılımcıların milli sporcu olup olmamasına göre zihinsel antrenman uygulamaları ile özgüven düzeylerinde anlamlı bir farklılık tespit edilememiştir $(\mathrm{P}>0,05)$ (Tablo 7).

Kulüp sporcusu olup olmama durumuna göre sporcuların zihinsel antrenman uygulamaları ve özgüven durumları Tablo 8'de verilmiştir.

Tablo 8: Kulüp Sporcusu Değişkenine Göre Sporcuların Zihinsel Antrenman Uygulamaları ile Özgüven Durumlarına İlişkin Analiz Sonuçları

\begin{tabular}{|c|c|c|c|c|c|c|c|}
\hline Alt Boyutlar & Kulüp Sporcusu & $\mathrm{n}$ & Ort. & Ss. & Ortanca & IQR & $\mathrm{P}$ \\
\hline \multirow{2}{*}{ Zihinsel Temel Beceriler* } & Evet & 159 & 15,65 & 3,34 & 16,00 & 3,0 & \multirow{2}{*}{0,495} \\
\hline & Hayır & 136 & 15,41 & 2,76 & 16,00 & 3,0 & \\
\hline \multirow{2}{*}{$\begin{array}{l}\text { Zihinsel Performans } \\
\text { Becerileri* }\end{array}$} & Evet & 159 & 22,01 & 4,25 & 22,00 & 5,0 & \multirow{2}{*}{0,401} \\
\hline & Hayır & 136 & 21,61 & 3,81 & 22,00 & 5,0 & \\
\hline \multirow{2}{*}{ Kişiler Arası Beceriler* } & Evet & 159 & 16,52 & 3,23 & 17,00 & 3,0 & \multirow{2}{*}{0,724} \\
\hline & Hayır & 136 & 16,39 & 2,65 & 17,00 & 2,0 & \\
\hline \multirow{2}{*}{$\begin{array}{l}\text { Kendinle Konuşma } \\
\text { Becerisi* }\end{array}$} & Evet & 159 & 11,75 & 2,63 & 12,00 & 3,0 & \multirow{2}{*}{0,286} \\
\hline & Hayır & 136 & 11,42 & 2,58 & 12,00 & 3,0 & \\
\hline \multirow{2}{*}{ Zihinsel Canlandırma* } & Evet & 159 & 11,79 & 2,70 & 12,00 & 3,0 & \multirow{2}{*}{0,938} \\
\hline & Hayır & 136 & 11,76 & 2,39 & 12,00 & 2,0 & \\
\hline \multirow{2}{*}{$\begin{array}{l}\text { Sporda Zihinsel Antrenman } \\
\text { Envanteri Toplam Puan* }\end{array}$} & Evet & 159 & 77,71 & 14,05 & 79,00 & 12,00 & \multirow{2}{*}{0,458} \\
\hline & Hayır & 136 & 76,59 & 11,27 & 78,00 & 12,00 & \\
\hline \multirow{2}{*}{ İç Özgüven } & Evet & 159 & 4,09 & 0,52 & & & \multirow{2}{*}{0,069} \\
\hline & Hayır & 136 & 3,97 & 0,57 & & & \\
\hline \multirow{2}{*}{ Dış Özgüven } & Evet & 159 & 4,04 & 0,55 & & & \multirow{2}{*}{0,220} \\
\hline & Hayır & 136 & 3,96 & 0,57 & & & \\
\hline \multirow{2}{*}{ Özgüven Toplam Puanı } & Evet & 159 & 4,06 & 0,50 & & & \multirow{2}{*}{0,105} \\
\hline & Hayır & 136 & 3,96 & 0,54 & & & \\
\hline
\end{tabular}

* ile gösterilenler parametrik olmayan teste (Mann Whitney U test) tabi tutulmuştur. 
Araştırmaya katılan sporcuların herhangi bir kulübe bağlı olup olmaması yönünden zihinsel antrenman uygulamaları ile özgüven düzeyleri açısından anlamlı bir farklılık tespit edilememiştir $(\mathrm{P}>0,05)$ (Tablo 8).

Farklı gelir düzeylerine sahip sporcuların zihinsel antrenman uygulamaları ve özgüven durumları Tablo 9'da verilmiştir.

Tablo 9: Gelir Düzeyi Değiş̧kenine Göre Sporcuların Zihinsel Antrenman Uygulamaları ile Özgüven Durumlarına İlişkin Analiz Sonuçları

\begin{tabular}{|c|c|c|c|c|c|c|c|}
\hline Alt Boyutlar & Gelir Düzeyi & $\mathrm{n}$ & Ort. & Ss. & Ortanca & IQR & $\mathrm{P}$ \\
\hline \multirow{3}{*}{ Zihinsel Temel Beceriler* } & Düşük & 89 & 15,18 & 3,36 & 16,00 & 4,0 & \multirow{3}{*}{0,059} \\
\hline & Orta & 174 & 15,55 & 2,87 & 16,00 & 3,3 & \\
\hline & Yüksek & 32 & 16,53 & 3,25 & 17,00 & 4,0 & \\
\hline \multirow{3}{*}{$\begin{array}{l}\text { Zihinsel Performans } \\
\text { Becerileri* }\end{array}$} & Düşük & 89 & $20,94 \mathrm{~b}$ & 4,34 & 22,00 & 5,0 & \multirow{3}{*}{0,046} \\
\hline & Orta & 174 & $22,01 \mathrm{ab}$ & 3,69 & 22,00 & 5,0 & \\
\hline & Yüksek & 32 & $23,31 \mathrm{a}$ & 4,60 & 23,00 & 6,0 & \\
\hline \multirow{3}{*}{ Kişilerarası Beceriler* } & Düşük & 89 & 15,94 & 3,44 & 16,00 & 3,0 & \multirow{3}{*}{0,034} \\
\hline & Orta & 174 & 16,59 & 2,56 & 17,00 & 2,0 & \\
\hline & Yüksek & 32 & 17,22 & 3,44 & 18,00 & 4,0 & \\
\hline \multirow{3}{*}{ Kendinle Konuşma* } & Düşük & 89 & $10,98 \mathrm{~b}$ & 3,00 & 12,00 & 4,0 & \multirow{3}{*}{0,008} \\
\hline & Orta & 174 & $11,74 \mathrm{~b}$ & 2,27 & 12,00 & 2,0 & \\
\hline & Yüksek & 32 & $12,59 \mathrm{a}$ & 2,77 & 13,00 & 4,0 & \\
\hline \multirow{3}{*}{ Zihinsel Canlandırma* } & Düşük & 89 & $11,20 \mathrm{~b}$ & 2,92 & 12,00 & 3,0 & \multirow{3}{*}{0,035} \\
\hline & Orta & 174 & $11,97 \mathrm{~b}$ & 2,31 & 12,00 & 3,0 & \\
\hline & Yüksek & 32 & $12,38 \mathrm{a}$ & 2,54 & 13,00 & 2,8 & \\
\hline \multirow{3}{*}{$\begin{array}{l}\text { Sporda Zihinsel Antrenman } \\
\text { Envanteri Toplam Puan* }\end{array}$} & Düşük & 89 & $74,25 \mathrm{~b}$ & 14,21 & 78,00 & 14,50 & \multirow{3}{*}{0,003} \\
\hline & Orta & 174 & $77,85 \mathrm{~b}$ & 11,40 & 78,00 & 12,25 & \\
\hline & Yüksek & 32 & 82,03 a & 14,48 & 84,00 & 13,75 & \\
\hline \multirow{3}{*}{ İç Özgüven } & Düşük & 89 & $3,96 \mathrm{~b}$ & 0,54 & & & \multirow{3}{*}{0,010} \\
\hline & Orta & 174 & $4,02 \mathrm{~b}$ & 0,55 & & & \\
\hline & Yüksek & 32 & $4,30 \mathrm{a}$ & 0,48 & & & \\
\hline \multirow{3}{*}{ Diş Özgüven } & Düşük & 89 & 3,94 & 0,55 & & & \multirow{3}{*}{0,124} \\
\hline & Orta & 174 & 3,99 & 0,55 & & & \\
\hline & Yüksek & 32 & 4,18 & 0,60 & & & \\
\hline \multirow{3}{*}{$\begin{array}{l}\text { Özgüven Ölçeği Toplam } \\
\text { Puanı }\end{array}$} & Düşük & 89 & $3,95 \mathrm{~b}$ & 0,51 & & & \multirow{3}{*}{0,026} \\
\hline & Orta & 174 & $4,01 \mathrm{~b}$ & 0,52 & & & \\
\hline & Yüksek & 32 & $4,24 \mathrm{a}$ & 0,50 & & & \\
\hline
\end{tabular}

* ile gösterilenler parametrik olmayan teste (Kruskal Wallis $\mathrm{H}$ test) tabi tutulmuştur.

Araştırmada sporcuların zihinsel performans becerileri, kendinle konuşma, zihinsel canlandırma alt boyutları ve sporda zihinsel antrenman envanteri toplam puanında ve anlamlı bir farkl1lık görülürken, zihinsel temel beceriler ve kişilerarası beceriler alt boyutlarında anlamlı farklılık tespit edilememiştir. Bununla birlikte sporcuların özgüven durumlarında ise iç özgüven ve özgüven ölçeği toplam puanında anlamlı bir farklılık görülürken, dış özgüven alt boyutunda anlamlı farklılık tespit edilememiştir. $(\mathrm{P}<0,05)$. (Tablo 9). 
Tablo 10: Sporcuların Sporda Zihinsel Antrenman Uygulamaları ile Özgüven Durumları Arasındaki İlişkiye Yönelik Yapılan Pearson Korelasyon Analiz Sonuçları

\begin{tabular}{|c|c|c|c|c|c|c|c|c|c|}
\hline & & $\begin{array}{l}\text { Özgüven } \\
\text { Toplam }\end{array}$ & İÖ & DÖ & $\begin{array}{l}\text { SZA } \\
\text { Toplam }\end{array}$ & ZTB & $\mathrm{ZPB}$ & $\mathrm{KB}$ & KK \\
\hline \multirow{2}{*}{ İç Özgüven (İ̈) } & $\mathrm{r}$ & 0,945 & & & & & & & \\
\hline & $\mathrm{p}$ & $<0,001$ & & & & & & & \\
\hline \multirow{2}{*}{ Dış Özgüven (DÖ) } & $\mathrm{r}$ & 0,940 & 0,778 & & & & & & \\
\hline & $\mathrm{p}$ & $<0,001$ & $<0,001$ & & & & & & \\
\hline \multirow{2}{*}{$\begin{array}{c}\text { Sporda Zihinsel } \\
\text { Antrenman Toplam } \\
\text { (SZA) }\end{array}$} & $\mathrm{r}$ & 0,432 & 0,416 & 0,408 & & & & & \\
\hline & $\mathrm{p}$ & $<0,001$ & $<0,001$ & $<0,001$ & & & & & \\
\hline \multirow{2}{*}{$\begin{array}{l}\text { Zihinsel Temel } \\
\text { Beceriler (ZTB) }\end{array}$} & $\mathrm{r}$ & 0,399 & 0,410 & 0,341 & 0,649 & & & & \\
\hline & $\mathrm{p}$ & $<0,001$ & $<0,001$ & $<0,001$ & $<0,001$ & & & & \\
\hline \multirow{2}{*}{$\begin{array}{c}\text { Zihinsel } \\
\text { Performans } \\
\text { Becerileri (ZPB) }\end{array}$} & $\mathrm{r}$ & 0,356 & 0,344 & 0,330 & 0,647 & 0,471 & & & \\
\hline & $\mathrm{p}$ & $<0,001$ & $<0,001$ & $<0,001$ & $<0,001$ & $<0,001$ & & & \\
\hline \multirow{2}{*}{$\begin{array}{c}\text { Kişileraras1 } \\
\text { Beceriler (KB) }\end{array}$} & $\mathrm{r}$ & 0,352 & 0,323 & 0,350 & 0,629 & 0,476 & 0,404 & & \\
\hline & $\mathrm{p}$ & $<0,001$ & $<0,001$ & $<0,001$ & $<0,001$ & $<0,001$ & $<0,001$ & & \\
\hline \multirow{2}{*}{$\begin{array}{l}\text { Kendinle Konuşma } \\
\text { (KK) }\end{array}$} & $\mathrm{r}$ & 0,237 & 0,237 & 0,223 & 0,558 & 0,329 & 0,305 & 0,397 & \\
\hline & $\mathrm{p}$ & $<0,001$ & $<0,001$ & $<0,001$ & $<0,001$ & $<0,001$ & $<0,001$ & $<0,001$ & \\
\hline \multirow{2}{*}{$\begin{array}{c}\text { Zihinsel } \\
\text { Canlandırma (ZC) }\end{array}$} & $\mathrm{r}$ & 0,264 & 0,254 & 0,257 & 0,638 & 0,433 & 0,386 & 0,498 & 0,477 \\
\hline & $\mathrm{p}$ & $<0,001$ & $<0,001$ & $<0,001$ & $<0,001$ & $<0,001$ & $<0,001$ & $<0,001$ & $<0,001$ \\
\hline
\end{tabular}

Araştırmada, sporcuların zihinsel antrenman uygulamaları ile özgüven düzeyleri arasındaki korelasyon sonuçları görülmektedir. Korelasyon analizi sonuçlarına göre sporcuların zihinsel antrenman uygulamaları ile özgüven düzeyleri arasında anlamlı düzeyde pozitif bir ilişki olduğu saptanmıştır.

\section{Tartışma ve Sonuç}

Bu çalışma, 2019-2020 Eğitim-Öğretim döneminde, Samsun Ondokuz Mayıs Üniversitesi Yaşar Doğu Spor Bilimleri Fakültesinde eğitimine devam etmekte olan sporcuların zihinsel antrenman uygulamaları ile özgüven düzeyleri arasındaki ilişkinin belirlenmesi amacıyla yapılmıştır. Çalışmada cinsiyet, yaş, milli sporcu olma ve kulüp sporcusu olma değişkenleri açısından sporcuların zihinsel antrenman uygulamaları ile özgüven düzeyleri arasında anlamlı bir ilişki bulunamazken; spor türü, spor yaşı, bölüm, ve gelir düzeyi değişkenleri açısından bazı alt boyutlarda anlamlı farklılık olduğu tespit edilmiştir.

Araştırma grubunun cinsiyet değişkenine göre sporda zihinsel antrenman envanteri ile özgüven ölçeğine verilen yantlar incelendiğinde istatiksel olarak anlamlı bir farkl1lık tespit edilememiştir. Bu durum, günümüzde kadınlarında erkekler kadar sporun içerisinde aktif olarak yer almaları ve sporcuların sporculuk seviyelerine bağlanabilir. Yapılan çalışmalara bakıldığında Karademir vd. (2018), Doğan (2019) ve Erdoğan ve Erhan (2019) yapmış oldukları çalışmalarda çıkan sonuçlar, bu araştırmanın sonucuyla benzerlik göstermektedir. Cebeci vd. (2019) ile Yarayan ve Ayan (2018)'ın yapmış oldukları çalışmalarda cinsiyet değişkenine göre anlamlı farklılık ortaya çıkmıştır. Çıkan sonuçlar mevcut araştırmanın sonuçlarıyla örtüşmemektedir. Yapılan araştırmada cinsiyet değişkenine göre elde edilen diğer bulgu ise sporcuların özgüven düzeylerine yöneliktir. Karacabey vd. (2017) ile Bilgin (2011)'in çalışmalarının sonuçları, araştırmanın sonucuyla paralellik 
göstermektedir. Alan yazın incelendiğinde, bu araştırmanın sonuçları ile örtüşmeyen çalışmalar mevcuttur. Ünsal (2019), Acuner (2012), Ekinci vd. (2011) ile Şar vd. (2010)'nn çalışmalarında cinsiyet değişkenine göre anlamlı düzeyde farklılık bulunmuştur.

Yapılan araştırma sonucunda; araştırmaya katılan sporcuların yaş değişkenine göre zihinsel antrenman uygulamaları ile özgüven düzeylerinde anlamlı bir farklılık tespit edilememiştir. $\mathrm{Bu}$ durumun araştırmaya katılan sporcuların belirli bir yaş grubunda yı ̆̆ılmasından kaynaklandığı söylenebilir. Kara ve Ustaoğlu Hoşver (2019) ile Cebeci vd. (2019)'nın yapmış oldukları çalışmalarda, zihinsel antrenman envanterinin bazı alt boyutlarında yaş değiş̧kenine göre anlamlı düzeyde farklılıklar ortaya çıkmıştır. Çıkan sonuçlar, bu araştırmanın sonuçlarıyla benzerlik göstermemektedir. Araştırmanın bir diğer bulgusu olan özgüven düzeyinde ise alan yazın incelendiğinde, Şar vd. (2010), Akkarpat (2014) ile Karacabey vd. (2017)'nın yapmış oldukları çalışmada yaş değişkenine göre anlamlı farklılık bulunamamıştır. Çıkan sonuç, bu araştırmanın sonucuyla benzerlik göstermektedir. Acuner (2012)'in yapmış olduğu çalı̧̧mada ise mevcut araştırmanın sonucundan farklı sonuç elde edildiği görülmektedir.

Araştırma grubunun spor türü değişkenine göre zihinsel antrenman envanterine ait kişilerarası beceriler ve zihinsel canlandırma alt boyutlarında anlamlı bir farklılık tespit edilmiş, diğer alt boyutlarda ve özgüven düzeylerinde anlamlı farklılık olmadığı saptanmıştır. Yapılan analizde, takım sporlarıyla ilgilenen sporcuların bireysel sporlarla ilgilenen sporculara göre kişilerarası beceriler ve zihinsel canlandırma alt boyut puan ortalamalarının daha yüksek olduğu tespit edilmiştir. Takım sporcularının birlikte hareket etmeleri, birbirleri ile etkileşim halinde olmaları ve sürekli iletişim kurma ihtiyaçları, kişilerarası beceri düzeylerine etki ettiği düşünülebilir. Bunun yanında takım sporcularının farklı sporcularla birlikte sportif faaliyetlerini sürdürmeleri ve farklı teknik ve taktik uygulamalarını gözlemleme şanslarının olması, zihinsel canlandırma uygulamalarına olumlu yönde etki edeceği söylenebilir. Erdoğan ve Erhan (2019)'ın sporcular üzerine yapmış olduğu imgeleme çalışması ile Ekinci vd. (2011)'nın yine sporcuların özgüven düzeylerini inceleyen çalışmalarının sonuçları, mevcut araştırmanın sonuçlarıyla örtüşmemektedir.

Araştırmanın, spor yaşı değişkenine göre sporcuların zihinsel antrenman uygulamaları ile özgüven durumlarına ilişkin yapılan analiz sonucunda, özgüven ölçeği toplam puanı ve alt boyutlarında; Sporda Zihinsel Antrenman Envanteri Toplam Puanında ve Kişilerarası Beceriler alt boyutunda anlamlı bir farklılık tespit edilmiştir. Yapılan analizde, sporcuların spor yaşları yükseldikçe zihinsel antrenman uygulamaları ve özgüven düzeyleri puan ortalamaları da yükseldiği tespit edilmiştir. Bu sonucu, sporcu yaşı fazla olan sporcuların, sporun içindeki tecrübelerine ve sporda özdeşleşme seviyelerine bağlanabilir. Güvendi vd. (2019) ile Kara ve Ustaoğlu Hoşver (2019)'in çalışmalarında ki sonuçlar, bu araştırmanın sonuçlarıyla benzerlik göstermektedir. Her iki araştırmada da spor yaşları arttıkça zihinsel antrenman uygulamaları üst seviyeye geldiği saptanmaktadır. Doğan (2019) ile Cebeci vd. (2019)'nın çalışmalarında ise spor yaşına göre anlamlı düzeyde farklılaşmadığı belirlenmiştir. Çıkan sonuçlar, yapılan araştırmanın sonucuyla benzerlik göstermemektedir.

Çalışmada, sporcuların okuduğu bölüm değişkenine göre incelendiğinde zihinsel antrenman envanteri, zihinsel performans becerileri alt boyutunda anlamlı bir farklılık tespit edilirken, diğer alt boyutlar ve özgüven düzeylerinde anlamlı farklılık olmadığı belirlenmiştir. Yapılan analizde, zihinsel performans becerileri alt boyutunda gruplar arası puan ortalamalarında fark çok az olarak tespit edilse de antrenörlük bölümünde okuyan sporcuların diğer bölümlerdeki sporculardan ortalamasının en yüksek olduğu belirlenmiștir. Bu sonucun, antrenörlük bölümünde okuyan sporcuların gerek ders müfredatlarının diğer bölümlere göre farklı olması gerekse de genel olarak o bölümdeki sporcuların her zaman sporun içinde aktif halde bulunması, zihinsel performans becerilerine olumlu yönde etki ettiği ifade edilebilir. 
Araştırmada sporcuların, milli sporcu ve kulüp sporcusu olup olmamasına göre zihinsel antrenman uygulamaları ile özgüven düzeylerinde anlamlı bir farklılık tespit edilememiştir. Ancak puan ortalamaları incelendiğinde zihinsel antrenman uygulama ve özgüven düzeylerinin milli sporcular ve herhangi bir kulübe bağlı sporcular puan ortalamalarının görülmüştür. Erdoğan ve Erhan (2019)'ın gerçekleştirmiş oldukları çalışmalarında, sporcuların millilik değişkeni bakımından anlamlı düzeyde farklılık görülmezken, milli sporcuların puan ortalamaları olmayanlara göre daha yüksek olduğu tespit edilmiştir. Böylece, bu çalışma sonucu ile mevcut araştırma sonucunun aynı şekilde olduğu belirlenmiştir.

Araştırmada sporcuların zihinsel antrenman uygulamaları gelir düzeyi değişkenine göre zihinsel performans becerileri, kendinle konuşma, zihinsel canlandırma alt boyutları ve sporda zihinsel antrenman envanteri toplam puanında anlamlı bir farklılık görülmüştür. Bununla birlikte sporcuların özgüven durumlarının gelir düzeyi değişkenine göre iç özgüven ve özgüven ölçeği toplam puanında anlamlı bir farklılık tespit edilmiştir. Yapılan analizde, sporcuların gelir düzeyi yükseldikçe zihinsel antrenman uygulamaları ve özgüven düzeylerinde de artış olduğu görülmektedir. Gelir düzeyi düşük olan sporcuların maddi kaygılarının antrenman süreçlerine ve kendilerine olan güvenlerine olumsuz yönde etki edeceği düşünülebilir. Bilgin (2011)'in ergenler üzerine yapmış olduğu çalışmada gelir düzeyleri yükseldikçe özgüvenlerinde de artış olduğunu belirlemiştir. Çıkan sonuç ile mevcut araştırmanın sonucu benzerlik göstermektedir. Yağan (2019) ve Gökkaya (2017)'nın çalışmalarında ise herhangi bir anlamlı farklılık bulunmazken, bu araştırma sonucu ile de örtüşmemektedir.

Araştırmada, sporcuların zihinsel antrenman uygulamaları ile özgüven durumları arasında pozitif bir ilişki olduğu saptanmıştır. Bu durumda, sporcuların performans sergiledikleri spor alanında zihinsel antrenman uygulamalarına yer verdikleri ve bunun özgüvene etki ettiği söylenebilir. Afacan (2019)'1n futbol hakemleri üzerine gerçekleştirmiş olduğu çalışmada, mevcut araştırma konusuyla kısmen benzerlik göstermekte ve hemen hemen aynı sonuçları ortaya çıkarmaktadır. Futbol hakemlerinin uyguladıkları psikolojik beceri antrenmanın özgüven düzeylerini geliştirdiğini göstermektedir. Sporcular, antrenmanda veya müsabakada performanslarındaki eksilerini ve artılarını hep görmektedirler. Bu durumu, olumlu bir şekilde değerlendirmek için, zihinsel antrenman uygulamaları şart olduğu söylenebilir. Böylece yapmış oldukları hataları göz önünde bulundurarak, tekrar etmemek adına zihinlerinde yer edinmeleri gerektiğinin farkına vardıkları düşünülebilir. Bununla birlikte sporcular ne kadar az hata yaparsa o kadar başarı seviyeleri yükselir ve kendilerine olan güvenleri en üst düzeye ulaşacağa ifade edilebilir. Sonuç olarak, sporcuların düzenli ve planlı bir şekilde zihinsel antrenman uygulamalarıyla birlikte hem başarı durumlarına hem de elde ettikleri başarı ile özgüven düzeylerine olumlu etki edeceği söylenebilir. Yapılan araştırma, farklı şekilde hakemlere, antrenörlere veya bireysel ve takım sporcularına da yapılabilir. Bunun yanında, mevcut araştırmanın sonuçlarına göre sporcuların performans seviyeleri ve tecrübelerine göre farklı farklı zihinsel antrenman uygulamaları önerilebilir.

\section{Kaynakça}

Acuner, A. (2012). Farklı dansları yapan bireylerin çeşitli değişkenlere göre özgüven ve özyeterliklerinin karşılaştırılması. Karadeniz Teknik Üniversitesi Eğitim Bilimleri Enstitüsü Beden Eğitimi ve Spor Anabilim Dalı, Yüksek Lisans Tezi.

Afacan, E. (2019). 6 haftalık psikolojik beceri (mental) antrenmanının futbol hakemlerinin özgüven, kayg1 ve mesleki tükenmişlik düzeylerine olan etkisi. Manisa Celal Bayar Üniversitesi Sağlık Bilimleri Enstitüsü Beden Eğitimi ve Spor Anabilim Dalı, Doktora Tezi.

Akandere, M., Aktaş S., Er Y. (2018). Zihinsel Antrenman ve Spor. Türkiye Barolar Birliği, 60-74. 
Akın, A. (2007). Öz-Güven ölçeği'nin geliştirilmesi ve psikometrik özellikleri. Abant İzzet Baysal Üniversitesi Eğitim Fakültesi Dergisi. 7/2, 167-176.

Akkarpat, İ. (2014). Farklı yaş gruplarında basketbolda imgelemenin serbest atış performansı, özgüven ve kaygı üzerine etkisi. Hacettepe Üniversitesi Sağlık bilimleri Enstitüsü Spor Bilimleri ve Teknolojisi Programı, Yüksek Lisans Tezi.

Behnke, M., Tomczak, M., Kaczmarak, L., Komar, M., Gracz, Z. (2017). The sport mental training questionnaire: development and validation. Current Psychology. 37, 1-13

Bilgin, O. (2011). Ergenlerde özgüven düzeyinin bazı değişkenler açısından incelenmesi. Sakarya Üniversitesi Eğitim Bilimleri Enstitüsü Eğitimde Psikolojik Hizmetler Anabilim Dalı, Yüksek Lisans Tezi.

Cebeci, C., Doğu Algün, G., Yılmaz, B. (2019). “'Badminton Sporcularının Zihinsel Antrenman Düzeylerinin İncelenmesi’”, 2. Uluslararası Herkes İçin Spor ve Wellness Kongresi, Antalya.

Doğan, E. (2019). “'Kadın ve erkek sporcuların imgeleme biçimlerinin karşılaştırılması”. Gaziantep Üniversitesi Spor Bilimleri Dergisi. 4/3, 373-381.

Ekinci, N.E, Özdilek, Ç., Deryahanoğlu, G., Üstün, Ü.D. (2014). “Spor yapan lise öğrencilerinin öz güven düzeylerinin incelenmesi’’. Sportif Bakış: Spor ve Eğitim Bilimleri Dergisi. 1/1, 36 42.

Erdoğan, N.G., Erhan, S.E. (2019). ' 'Kış sporları ile ilgilenen sporcuların sporda imgeleme ile sportif güven arasındaki ilişkinin incelenmesi”. Uluslararası Egzersiz Psikolojisi Dergisi. 1/2, 1422 .

Gökkaya, D. (2017). Psikolojik beceri kıstası olarak özgüvenin, elit sporcuların performansına katkısı; boks milli takımı örneği. Marmara Üniversitesi Sağlık Bilimleri Enstitüsü, Yüksek Lisans Tezi.

Güvendi, B., Güçlü, M., Türksoy Işım, A. (2019). "Psikolojik performans stratejileri uygulamalarının bazı bağımsız değişkenlere gör incelenmesi”". Turkish Studies. 14/3, 14991512.

Kara, Ö., Ustaoğlu Hoşver, P. (2019). "Play-off müsabakalarında yer alan kadın voleybolcuların zihinsel antrenman düzeylerinin çeşitli değişkenler açısından incelenmesi’'. İnternational Sport Science Student Studies. 1/1, 35-42.

Karacabey, K., Apur, U., Öntürk, Y., Akyel, Y. (2017). "Ergen sporcuların kayg1 ve kendine güven düzeylerinin bazı değişkenler açısından incelenmesi: sporcu eğitim merkezleri örneği’’. Batman Üniversitesi Yaşam Bilimleri Dergisi. 7/2, 111/121.

Karademir, T., Türkçapar, Ü., Açak, M., Eroğlu, H. (2018). “Bireysel ve takım sporu ile uğraşan sporcularda hayal etme biçimlerinin incelenmesi". Atatürk Üniveristesi Beden Eğitimi ve Spor Bilimleri Dergisi. 20/3, 92-102.

Karasar, N. (2000). Bilimsel Araştırma Yöntemleri, Nobel Yayın Dağıtım, 10. Baskı, Ankara.

Koruç, Z., Bayar, P. (1990). Kitle sporu ve spor psikolojisi. Spor ahlaki ve spor felsefesine yeni yaklaşımlar sempozyumu, İstanbul Üniversitesi, 115-118.

Şar, A.H., Avcu, R., Işıklar, A. (2010). “Analyzing undergraduate students self confidence levels in terms of some variables". Procedia Social and Behavioral Sciences 5, 1205-1209.

Ünsal, G.H. (2019). Spor yapan ve yapmayan lise öğrencilerinin özgüven, öz-yeterlik ve iletişim becerilerinin incelenmesi. Ondokuz Mayıs Üniversitesi Sağlik Bilimleri Enstitüsü Beden Eğitimi ve Spor Anabilim Dalı, Yüksel Lisans Tezi. 
Yağan, K. (2019). Fitness merkezine giden bireylerin sosyal görünüş kaygısı ve özgüven düzeylerinin incelenmesi. Karamanoğlu Mehmetbey Üniversitesi Sosyal Bilimler Enstitüsü, Beden Eğitimi ve Spor Anabilim Dalı, Yüksek Lisans Tezi.

Yarayan, Y.E., Ayan, S. (2018). "Farklı takım sporlarında olan sporcuların imgeleme biçimlerinin incelenmesi”. Uluslararası Sosyal Araştırmalar Dergisi. 11/60, 1415-1422.

Yarayan, Y.E., İlhan, E.L. (2018). “Sporda zihinsel antrenman envanteri'nin (szae) uyarlama çalışması"'. Gazi Beden Eğitimi ve Spor Bilimleri Dergisi. 23/4, 205-218. 